\title{
Students' Perception on the Use of Digital Mind Map to Stimulate Creativity and Critical Thinking in ESL Writing Course
}

\author{
Rafidah Abd Karim ${ }^{1, *}$, Ramlee Mustapha ${ }^{2}$ \\ ${ }^{1}$ Academy of Language Studies, Universiti Teknologi MARA, Perak Branch, Tapah Campus, Tapah Road, Malaysia \\ ${ }^{2}$ Faculty of Technical and Vocational Education, Universiti Pendidikan Sultan Idris, Tanjong Malim, Malaysia
}

Received August 20, 2020; Revised November 15, 2020; Accepted November 29, 2020

\section{Cite This Paper in the following Citation Styles}

(a): [1] Rafidah Abd Karim, Ramlee Mustapha, "Students' Perception on the Use of Digital Mind Map to Stimulate Creativity and Critical Thinking in ESL Writing Course," Universal Journal of Educational Research, Vol. 8, No. 12A, pp. 7596 - 7606, 2020. DOI: 10.13189/ujer.2020.082545.

(b): Rafidah Abd Karim, Ramlee Mustapha (2020). Students' Perception on the Use of Digital Mind Map to Stimulate Creativity and Critical Thinking in ESL Writing Course. Universal Journal of Educational Research, 8(12A), 7596 - 7606. DOI: 10.13189/ujer.2020.082545.

Copyright $\bigcirc 2020$ by authors, all rights reserved. Authors agree that this article remains permanently open access under the terms of the Creative Commons Attribution License 4.0 International License

\begin{abstract}
In practise, mind maps have long been used by individuals especially teachers to create, visualise, arrange, and expand ideas in order to facilitate teaching and learning. Learning visually is a distinctive technique in modern pedagogy because most individuals are visual learners. As technology advances, digital mind map is created to replace manual mind map to bring modern pedagogy into the era of the fourth industrial revolution. Digital mind map has been used by teachers to teach diverse subjects. However, the use of digital mind map in teaching writing is scarce. Hence, the purpose of this case study was to examine the use of digital mind map to stimulate creativity and critical thinking in ESL writing course. A sample of 32 university students was selected randomly from one public university in Malaysia. The researchers developed a set of questionnaires to measure the three constructs - the usage of digital mind map, creativity, and critical thinking in writing tasks based on these three models: Lin \& Faste, William, and Watson-Glaser models. The empirical results showed that the use of digital mind map evidently stimulates the students' creativity and critical thinking in completing their writing tasks as perceived by the respondents. Thus, the use of digital mind map has facilitated the ESL students' writing tasks in terms of integrating creative and critical elements.
\end{abstract}

Keywords Digital Mind Map, Creativity, Critical
Thinking, Writing Tasks, ESL Students

\section{Introduction}

The Malaysian Education Blueprint 2013-2025 has highlighted the critical areas for preparing students for the $21^{\text {st }}$ century which include creativity, critical thinking, communication, and collaboration skills. Critical and creative thinking are salient competencies in future workplace. Furthermore, problem-based learning is also critical in the new era of digital transformation [1]. In the context of language learning, communicative competence especially in writing is pertinent to produce future writers and thinkers. Writing is a creative process which requires those who teach writing to devise diverse approaches and strategies to teaching writing [2]. In addition, integrating critical thinking in writing is a crucial process in developing the students' communicative competence. Positive attitudes towards writing in English is also important especially for ESL students [3]. In writing, students should plan their works first in a pre-writing stage. By planning the writing, the students would be able to think and brainstorm their ideas and organise their ideas effectively. Mind maps have been used in brainstorming sessions and other ideas branching activities [4]. With the 
advent of digital technology, digital mind map was introduced that uses computer-generated visual diagrams to facilitate teaching and learning. In other words, by using the digital mind map, the students can create hyperlink and a dynamic mind map that could digitally link diverse ideas. With faster speed, digital mind map is poised to generate critical and creative ideas in complex tasks such as writing. Before we go any further, the epistemology of digital mind map is discussed.

\subsection{Digital Mind Map}

Digital mind maps include both digital pictorial and text information and allow ideas to be externalized as a structured neural network including textual and visual images of concepts originating from a central idea and to be disseminated as branches of related information [5, 6]. In the literature, past research has found that digital mind mapping can be used to enhance both individual and collaborative learning [7]. Due to the advent of technology, the digital mind map could be used as a dynamic tool that is expected to have a great impact on teaching and learning domain especially in today's socially mobile environment [8]. A transformation from pen and paper technique to a digital tool has shown a range of benefits for brainstorming session among students [9]. In addition, the pen and paper technique took more time, waste materials, and effort [10].

Writing needs creativity and imagination to carry the author's ideas to a vivid reality on paper. In writing classes, the visual experience is the main way students make sense of the world, so it is normal for them to use a visual tool to decipher their ideas. Hence, digital mind map could assist the students to build and organise their ideas and to develop their writing competency.

When it comes to writing, the digital mind map allows students to brainstorm and organise their thoughts [11]. In other words, the digital mind map helps the learners to organise their writing. For example, "Mindomo" helps users brainstorm ideas with colourful digital mind maps and design ideas professionally [12]. In addition, digital mind mapping could facilitate writing process because the digital tool can integrate ideas with other relevant symbols, colours, and nodes [13]. Another research also suggested that more studies are required to explore the impact of the digital mind map technique on creative thinking [14]. In developing creative ideas to be put in the writing, the digital mind map tends to offer various advantages.

\subsection{Creativity}

Creativity is one of the key skills of the 21 st century. It is a cognitive ability to generate novel and useful ideas. New ideas often come when someone is thinking "outside of the box". Creativity often relies on imagination. Hence, imagination is equally important in the process of creating new ideas. In writing, students need to be creative in getting varied ideas and perspectives. The creativity of the students could be strengthened by language instruction [15]. In this study, we focused on writing as one of the language skills. Creative writing is an innovative process with the goal of creating new type of written genre [16]. The goal of creative writing training is to spark novel thought, concept, or story in their mind, so that students can start writing and enhance their writing skills quickly and easily. In this study, we assume digital mind map could be effective in enhancing creativity in the writing process.

Creative writing could be a means for students to enhance their communicative competence. In completing their writing task, the students need to communicate their thoughts, aspirations, and emotions in an articulate, critical, and creative manner. Nevertheless, for teachers, teaching writing to ESL students is a challenging activity. Jarf's study [17] indicated that a creative way how to improve creative writing by non-native English speakers is to write in social media.

Regarding the writing activity, in a study conducted in Turki found that the students' academic achievement in Turkish classroom was strengthened by creative writing exercises [18]. In another study, a multimethod approach was found to be effective in supporting reflection and creativity in online collaborative courses [19]. Several studies have shown that there is a need to develop students' creativity in higher educational institutions [20]. Besides creativity, literature has shown that critical thinking is also a key component in a writing process.

\subsection{Critical Thinking}

Critical thinking is one of the qualities that students need to learn, develop and apply in their future work. In general, critical thinking could be defined as a cognitive process that a person is actively and skillfully conceptualising, applying, analysing, criticising, synthesising, and evaluating information based on evidence and logic. If a person has logical thinking ability, he or she can understand the connection between concepts and can solve problems in a clear manner. In writing, critical thinking skills should be applied by the students in their writing process. For example, to produce ideas objectively, to test their claims, to make inference, and to make decisions. Hence, thinking critically is also useful for students to improve their writing skills [21].

According to Balta [22], however, integrating critical thinking to improve writing skills is a challenge. In Turkey, not many writing materials like textbooks that embed critical thinking. Hence, it is critical to incorporate critical thinking in writing tasks to improve the students' writing skills. In another study, Nawas [23] applied the Contextual Teaching and Learning (CTL) approach in teaching writing and found a positive impact of the approach on students' critical thinking in writing. In 
addition, Oz \& Memis [24] found at the elementary school level, the use of multi-modal representation strategy was effective to connect critical thinking to writing skills. Hence, teachers should be encouraged to apply different strategies, including digital mind map to integrate critical thinking skills in the teaching of writing especial for ESL students.

\section{Problem Statement}

Literature has shown that ESL students have difficulty in writing in English. Writing is a challenging and complex task because it involves various skills [25]. In Malaysia where English is a second language and most students have gone through at least eleven years of formal ESL education in schools but most university students are still experiencing difficulties in writing in English due to a variety of factors. One of the factors is that most students are unable to brainstorm and develop their ideas in writing. The problem could be closely linked to poor imagination and weak critical thinking skills. In addition, lack of a proper tool to synchronise their ideas into making a cohesive and coherence piece of writing is deemed as another key predicament.

Even though the students have a lot of ideas that flow in their minds but they often lack the skills to coordinate these ideas and they appear to think too long on those ideas. This may make them drift away from analyzing and synthesising the ideas. Lacking of logical connectors, their ideas may be jumping around and they may experience flights of ideas. Furthermore, using pen and paper technique is not too effective in improving the university students' writing skills because the students need some time to produce their ideas. Therefore, students need an advanced technique to create and generate ideas for their writing. Therefore, the purpose of this study was to examine the use of digital mind map to stimulate creativity and critical thinking in students' writing course

\section{Purpose and Objectives of the Study}

The purpose of this study was to identify students' perception on the use of digital mind map to stimulate creativity and critical thinking in ESL writing course. Specifically, the objectives of the study were as follows:

- To identify the students' perceptions on the use of the digital mind map

- To examine the students' creativity in writing after using the digital mind map

- To examine the students' critical thinking in writing after using the digital mind map

- To determine the relationship between the use of the digital mind map and students' creativity in writing

- To determine the relationship between the use of the digital mind map and students' critical thinking in writing

\section{The Conceptual Framework}

Figure 1 shows the conceptual framework of the study. The framework focuses on three main constructs: (a) the use of digital mind map, (b) creativity in writing, and (c) critical thinking in writing. The concept of digital mind map was based on Lin \& Faste [26] model. The key elements in the digital mind map were: speed and efficiency, appearance and mechanics and ontology and concept mapping [26].

Next, the second construct - creativity in writing was based on William's model [27]. In the model, there are four main skills: fluency, flexibility, originality, and elaboration for evaluating creativity in writing. Finally, the third construct was critical thinking in writing. This construct was based on Watson-Glaser thinking appraisal model [28]. Critical thinking construct consisted of three main skills: recognise assumptions, evaluate arguments, and draw conclusions.

Digital mind map was designated as an independent variable and creativity and critical thinking were classified as dependent variables. Another category of variable was moderator variable that comprised the demographics of the respondents such as gender, age, and home town (rural vs. urban).

In this conceptual framework, it was hypothesized that the digital mind map was expected to influence the creativity and critical thinking of the respondents in their writing tasks. 


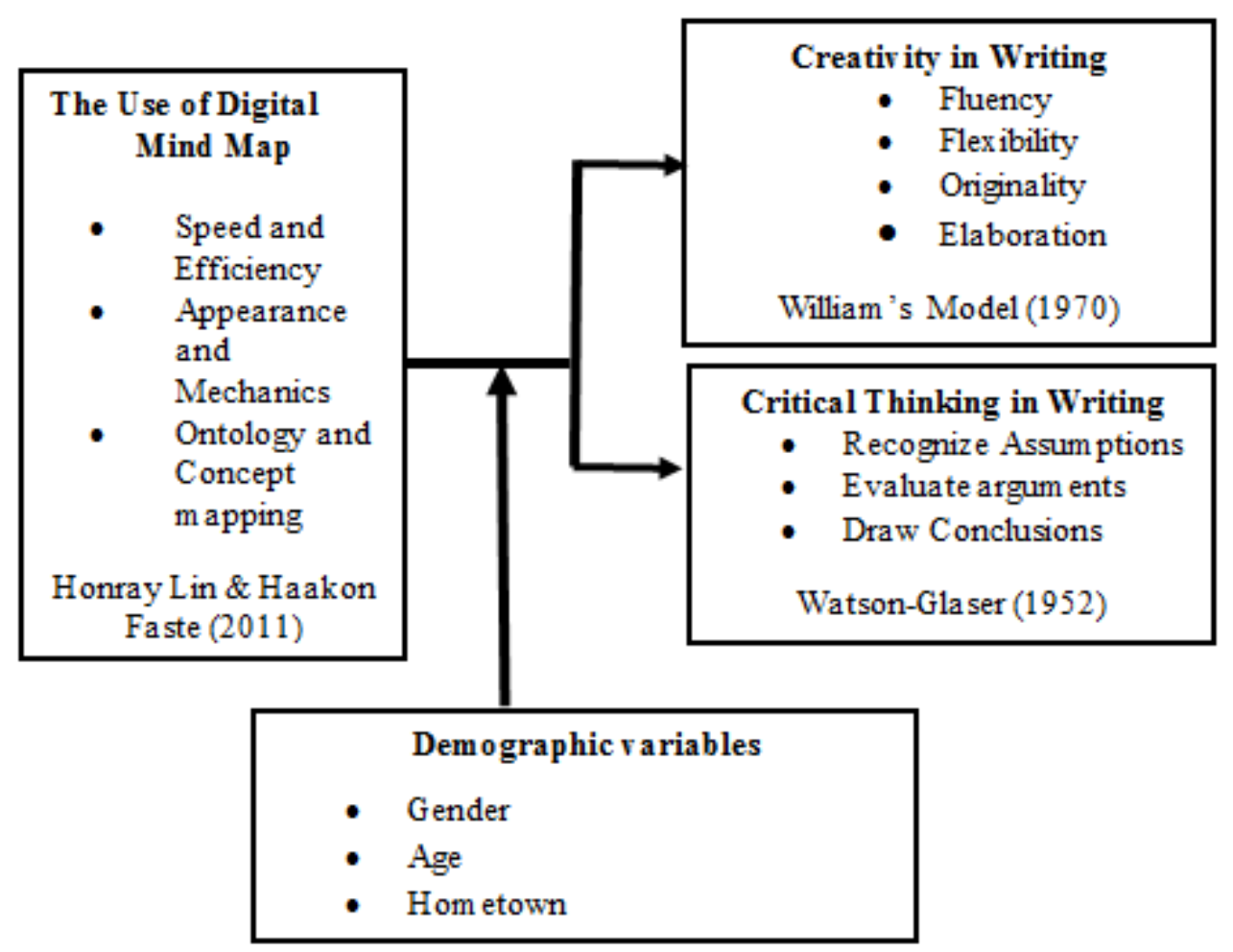

Figure 1. Conceptual Framework for Stimulating Creativity and Critical Thinking in Writing Course

\section{Methods}

This study used a case study design to examine the use of digital mind map to stimulate creativity and critical thinking in students' writing course. The researchers developed an online questionnaire based on the three models: Lin \& Faste model [26], William's model [27] and Watson-Glaser model [28]. We adapted and designed the questionnaire items based on Lin \& Faste model which included the three main sections: speed and efficiency, appearance and mechanics, and ontology and concept mapping. The items were constructed to measure the use of the digital mind map among students. Next, we employed William's model to develop creativity questionnaire items that consisted of four the elements: fluency, flexibility, originality, and elaboration. The items were constructed to measure the students' creativity in writing. Finally, we applied Watson-Glaser model to develop critical thinking questionnaire which comprised three sub-constructs: recognise assumption, evaluate arguments and draw conclusions. The questionnaire items were designed to measure the students' critical thinking in writing.

The overall questionnaire consisted of five sections: (A) Student Profile (6 items), (B) The Use of Digital Mind Map (18 items), (C) The Use of Digital Mind Map to Stimulate Creativity (24 items), (D) The Use of Digital Mind Map to Stimulate Critical Thinking (18 items) and six open-ended items (E). The students were asked to respond to a total of 66 items of the questionnaire. The respondents were also asked to answer open-ended items in the part $\mathrm{E}$ of the questionnaire to obtain qualitative inputs regarding the factors that support or suppress the quality of students' writing using the digital mind map. The questionnaire items for Section B, C and D were measured by using 5-point Likert scale: strongly agree (5), agree (4), uncertain (3), disagree (2) and strongly disagree (1). The instruments were validated by three experts in the field. And, the reliability of the instrument was determined by using Cronbach Alpha coefficient, $\alpha=$ 0.99 .

The online questionnaires were administered to the respondents. The respondents of the study were $32 \mathrm{ESL}$ students out of a total of 180 Diploma students who took the writing course at one of the selected public universities in Malaysia. The students were registered for English Writing Course for Semester 3. The number of respondents was randomly selected based on sample size table formula of Krejcie and Morgan. A random sample of 32 ESL students was selected from writing classes. The students were taught by instructors how to use and practice the digital mind mapping in the classroom for four-week. Then, they were given several writing topics for their assignments. The writing topics included "Ways to have a healthy diet", "How one can gain benefits from participating in voluntary work", "Ways to overcome stress during Covid-19 Pandemics", "Is television good or bad?" and "The grading system should not exist to judge a student's abilities". The students were asked to write their essays using the digital mind map as a visual tool. At the 
end of their course, they were asked to fill in the online survey questionnaire regarding the effect of digital mind map on their creativity and critical thinking in writing.

The data from the Likert scale items were analysed using descriptive and inferential statistics such as frequency, percentage, mean, standard deviation (SD) and Pearson correlation. The open-ended items were analysed using thematic analysis using Miles and Huberman's method. The research question (RQ) of the study were:

RQ 1: What are the students' perceptions on the use of the digital mind map?

RQ 2: What are the students' creativity in writing after using the digital mind map?

RQ 3: What are the students' critical thinking in writing after using the digital mind map?

RQ 4: What is the relationship between the use of digital mind map and the students' creativity in writing?

RQ 5: What is the relationship between the use of digital mind map and ESL students' critical thinking in writing?

\section{Results and Discussion}

\subsection{Profile of the Respondents}

Table 1. Profile of the Respondents ( $n=32)$

\begin{tabular}{|c|c|c|}
\hline Characteristics & Frequency & $\%$ \\
\hline \multicolumn{3}{|l|}{ Gender } \\
\hline Male & 8 & 25 \\
\hline Female & 24 & 75 \\
\hline \multicolumn{3}{|l|}{ Age (years) } \\
\hline $17-19$ years & 1 & 3.1 \\
\hline 20-22 years & 31 & 96.9 \\
\hline \multicolumn{3}{|c|}{ Location of Hometown } \\
\hline City & 17 & 53.1 \\
\hline Suburban & 9 & 28.1 \\
\hline Rural & 6 & 18.8 \\
\hline \multicolumn{3}{|c|}{ Do you like learning English writing? } \\
\hline Yes & 31 & 96.9 \\
\hline No & 1 & 3.1 \\
\hline \multicolumn{3}{|c|}{ Do you know what a digital mind map is? } \\
\hline Yes & 32 & 100 \\
\hline No & 0 & 0 \\
\hline \multicolumn{3}{|c|}{$\begin{array}{l}\text { Have you ever used digital mind mapping for } \\
\text { learning? }\end{array}$} \\
\hline Yes & 29 & 90.6 \\
\hline No & 3 & 9.4 \\
\hline
\end{tabular}

Table 1 displayed the profile of the respondents. A total of 32 respondents consisted of 8 male (25\%) and 24 female $(75 \%)$ students. Most of the respondents' age were between 20-22 years old (96.9\%). Majority of the respondents $(81.2 \%)$ stayed in either city or suburban areas whereas only 6 respondents $(18.8 \%)$ came from rural area. Students were also asked about the information on digital mind mapping and writing background. From Table 1, it showed that most respondents (96.9\%) like to learn English writing and only one student did not like to learn English writing. All the respondents $(100 \%)$ said that they knew how to use the digital mind map tool. However, 29 respondents (90.6\%) said that they used to practice the tool for learning whereas three students $(9.4 \%)$ never used the tool before.

The results of the study were arranged based on the structures of the questionnaire. The interpretation for the mean values in this study was divided into five parts: Strongly Agree (4.21-5.00), Agree (3.41- 4.20), Uncertain (2.61-3.40), Disagree (1.81-2.60) and Strongly Disagree (1.00-1.80). In the Likert scale section, we described the results of the three highest mean and the three lowest mean values of the items.

\subsection{The Use of Digital Mind Map}

To answer Research Question1, Table 2 showed the items that measured the use of the digital mind map in the writing class. The items were categorised under three areas: speed and efficiency (6 items), appearance and mechanics (6 items), and ontology and concept mapping (6 items).

Based on the findings, the three highest means indicated that the respondents believed that the digital mind map has enabled them to drag their ideas, enlarge lines and use pictures easily $(\mathrm{M}=4.03 ; \mathrm{SD}=0.82)$. The users enjoyed using digital mind map because they could also add colours, nodes and links while creating the digital mind maps so it made learning process fun $(\mathrm{M}=4.03$; SD $=0.82$ ). The students concurred that digital mind map helped them to organise their ideas in a structural way and thus enhanced their understanding of concepts and ideas in their writing $(\mathrm{M}=4.03 ; \mathrm{SD}=0.82)$.

However, among the lowest means included that the respondents barely agreed $(\mathrm{M}=3.75 ; \mathrm{SD}=1.08)$ that digital mind map was faster than using pen and paper to create mind maps. And that the respondents slightly agreed that digital mind map gave them more space than using pen and paper to create mind maps $(\mathrm{M}=3.78 ; \mathrm{SD}=$ $0.98)$. The users also slightly agreed that they save a lot of time when using digital mind map $(\mathrm{M}=3.81 ; \mathrm{SD}=0.81)$. 
Table 2. Mean and Standard Deviation for the Use of Digital Mind Map

\begin{tabular}{|c|c|c|c|c|}
\hline Item & Construct & $\mathbf{M}$ & SD & Interpretation \\
\hline & Speed and Efficiency & & & \\
\hline 1 & I create ideas faster when I use the digital mind map & 3.81 & 0.93 & Agree \\
\hline 2 & I store my ideas effectively when I use the digital mind map & 4.00 & 0.88 & Agree \\
\hline 3 & $\begin{array}{l}\text { I found that using the digital mind map is faster than using pen and } \\
\text { paper to create mind maps }\end{array}$ & 3.75 & 1.08 & Agree \\
\hline 4 & $\begin{array}{l}\text { I found that the digital mind map gives more space than using pen and } \\
\text { paper to create mind maps }\end{array}$ & 3.78 & 0.98 & Agree \\
\hline 5 & $\begin{array}{l}\text { When I edit my ideas, the digital mind map enables me to drag ideas, } \\
\text { enlarge lines and use pictures easily }\end{array}$ & 4.03 & 0.82 & Agree \\
\hline \multirow[t]{2}{*}{6} & $\begin{array}{l}\text { While using the digital mind map, I saved my time a lot because the } \\
\text { software allowed me to work faster }\end{array}$ & 3.81 & 0.81 & Agree \\
\hline & Appearance and Mechanics & & & \\
\hline 7 & I design the digital mind map contents very well & 3.78 & 1.04 & Agree \\
\hline 8 & I insert text input easily using the digital mind map & 3.91 & 0.89 & Agree \\
\hline 9 & I save and retrieve stored information easily using the digital mind map & 4.00 & 0.84 & Agree \\
\hline 10 & $\begin{array}{l}\text { I found that using colours, nodes and links while creating the digital } \\
\text { mind maps make learning process at ease }\end{array}$ & 4.03 & 0.82 & Agree \\
\hline 11 & $\begin{array}{l}\text { I found that dragging one node into another could easily create a link } \\
\text { between them when using the digital mind map }\end{array}$ & 3.88 & 0.87 & Agree \\
\hline \multirow[t]{2}{*}{12} & $\begin{array}{l}\text { I found that the navigation and layout mechanics of digital mind maps } \\
\text { represent a prospective digital tool }\end{array}$ & 3.88 & 0.79 & Agree \\
\hline & Ontology and Concept Mapping & & & \\
\hline 13 & By using digital mind mapping, I organise my ideas in a structural way & 4.03 & 0.86 & Agree \\
\hline 14 & $\begin{array}{l}\text { Digital mind mapping enhances my understanding of concepts and } \\
\text { ideas in writing }\end{array}$ & 4.03 & 0.82 & Agree \\
\hline 15 & I understand the relationships across ideas within the digital mind map & 4.00 & 0.84 & Agree \\
\hline 16 & I generate ideas using the digital mind map effectively & 3.91 & 1.06 & Agree \\
\hline 17 & $\begin{array}{l}\text { I found that the digital mind maps helped me to organise my ideas in } \\
\text { writing }\end{array}$ & 3.84 & 0.85 & Agree \\
\hline \multirow[t]{2}{*}{18} & I believe that the digital mind is a great tool to link and organise ideas & 4.00 & 0.80 & Agree \\
\hline & Total average & 3.92 & 0.76 & Agree \\
\hline
\end{tabular}

\subsection{Creativity in Writing}

The results of the perceived effect of the digital mind mapping on the respondents' creativity in writing were described in Table 3. To answer Research Question 2, Table 3 illustrated the means, standard deviations, and the interpretations for the perceived effect of the digital mind map to stimulate creativity in writing. The construct comprised 24 items were divided into four main skills: fluency (6 items), flexibility (6 items), originality (6 items), and elaboration (6 items). Based on Table 3, among the three highest means indicated that the students strongly agreed $(\mathrm{M}=4.37 ; \mathrm{SD}=0.66)$ that creativity was important to generate diversity of ideas in writing. Also, the respondents strongly believed $(\mathrm{M}=4.25 ; \mathrm{SD}=0.62)$ that good ideas would be generated from creativity. The third highest mean specified that users organized their main and sub-ideas creatively in writing $(\mathrm{M}=4.09 ; \mathrm{SD}=$ $0.73)$.

The lowest means in this section included that the respondents hardly agreed $(M=3.66 ; \mathrm{SD}=0.97)$ that they used nodes and links to generate new ideas. Next, the students barely agreed $(3.69 ; \mathrm{SD}=0.99)$ that they became expert in identifying the main and sub-ideas in writing by using digital mind map. And the third lowest mean indicated that the users slightly agreed $(\mathrm{M}=3.72 ; 0.89)$ that they produced totally new original ideas. Nevertheless, in the nutshell, the results showed the positive attitude of the respondents regarding the effect of the digital mind map on their creativity in writing. The findings are similar with a study that supports the use of digital mind map strategy to stimulate and enhance students' creativity [30]. 
Table 3. The Use of Digital Mind Map to Stimulate Creativity in Writing

\begin{tabular}{|c|c|c|c|c|}
\hline Item & Construct & $\mathbf{M}$ & SD & Interpretation \\
\hline & Fluency & & & \\
\hline 19 & I believe creativity is important to produce a lot of ideas in writing & 4.37 & 0.66 & Strongly Agree \\
\hline 20 & I believe creativity in writing is important for producing good ideas & 4.25 & 0.62 & Strongly Agree \\
\hline 21 & I develop my new ideas in writing through digital mind map & 3.78 & 0.91 & Agree \\
\hline 22 & $\begin{array}{l}\text { I enhance my creativity by identifying main ideas and sub ideas in writing } \\
\text { through the digital mind map }\end{array}$ & 3.88 & 0.91 & Agree \\
\hline 23 & $\begin{array}{l}\text { I have improved my confident level in creating new ideas in writing through } \\
\text { creativity when I use the digital mind map }\end{array}$ & 3.75 & 0.84 & Agree \\
\hline \multirow[t]{2}{*}{24} & $\begin{array}{l}\text { I became expert in identifying the main ideas and the sub ideas in writing in } \\
\text { more creative ways through the digital mind map }\end{array}$ & 3.69 & 0.99 & Agree \\
\hline & Flexibility & & & \\
\hline 25 & I think new ideas in writing through the digital mind map & 3.84 & 0.92 & Agree \\
\hline 26 & I produce ideas in various ways when I write essays using the digital mind map & 3.78 & 0.87 & Agree \\
\hline 27 & $\begin{array}{l}\text { I feel motivated to produce more creative ideas in writing using the digital mind } \\
\text { map }\end{array}$ & 3.78 & 0.98 & Agree \\
\hline 28 & I have the ability to visualize creative ideas for my writing topic & 4.00 & 0.72 & Agree \\
\hline 29 & $\begin{array}{l}\text { I found that I can produce the main ideas and sub ideas in various ways while } \\
\text { writing }\end{array}$ & 4.09 & 0.78 & Agree \\
\hline \multirow[t]{2}{*}{30} & $\begin{array}{l}\text { I found that I can imagine and produce ideas in writing easily through the digital } \\
\text { mind map }\end{array}$ & 3.78 & 0.83 & Agree \\
\hline & Originality & & & \\
\hline 31 & I create original ideas in writing through the digital mind map & 3.72 & 0.89 & Agree \\
\hline 32 & I think new ideas while writing through the digital mind & 3.81 & 0.78 & Agree \\
\hline 33 & $\begin{array}{l}\text { I generate new ideas creatively in writing when I use nodes and links while } \\
\text { creating the digital mind map }\end{array}$ & 3.66 & 0.97 & Agree \\
\hline 34 & $\begin{array}{l}\text { I create original main ideas and original sub ideas in writing through the digital } \\
\text { mind map }\end{array}$ & 3.97 & 0.82 & Agree \\
\hline 35 & $\begin{array}{l}\text { I identify the main ideas and the sub ideas in writing in more creative ways using } \\
\text { the digital mind map }\end{array}$ & 3.84 & 0.85 & Agree \\
\hline \multirow[t]{2}{*}{36} & writing in ideas original produce to me helped map mind digital the that found I & 3.84 & 0.85 & Agree \\
\hline & Elaboration & & & \\
\hline 37 & I organise my ideas in writing in a new way through the digital mind map & 4.00 & 0.76 & Agree \\
\hline 38 & I organise the main ideas and the sub ideas in writing in a creative way & 4.09 & 0.73 & Agree \\
\hline 39 & I became expert in organizing my writing information creatively & 3.84 & 0.81 & Agree \\
\hline 40 & $\begin{array}{l}\text { I found that I can organise my ideas easier in writing when I use the digital mind } \\
\text { map }\end{array}$ & 3.78 & 0.94 & Agree \\
\hline 41 & I organise my previous ideas in writing easily when I use the digital mind map & 3.81 & 0.97 & Agree \\
\hline \multirow[t]{2}{*}{42} & $\begin{array}{l}\text { When I used nodes and links while organizing my ideas in writing, it made my } \\
\text { learning easier and more creative }\end{array}$ & 3.87 & 0.91 & Agree \\
\hline & Total average & 3.89 & 0.69 & Agree \\
\hline
\end{tabular}

\subsection{Critical Thinking in Writing}

The third Research Question was posited to ask the respondents to rate their critical thinking in writing. The researchers have constructed 18 items to measure the students' critical thinking in writing after using the digital mind map (see Table 4). There were three sub-constructs included recognise assumptions (6 items), evaluate arguments (6 items), and draw conclusions (6 items) as stipulated in Table 4. The table displayed the means, standard deviations, and the interpretations for the perceived effect of the digital mind map to stimulate critical thinking in writing.

The highest mean for critical writing after using digital mind map was that the students believed $(\mathrm{M}=4.09 ; \mathrm{SD}=$ 0.73 ) that they could solve problem by thinking critically. It followed with the claim that the respondents could stimulate critical thinking by recognising ideas $(\mathrm{M}=4.06$; $\mathrm{SD}=0.84)$. The third highest mean indicated that the respondents concurred $(\mathrm{M}=4.03 ; \mathrm{SD}=0.70)$ that they were able to make decision to retain the relevant information and to discard the irrelevant information in their writing. The results were quite similar with the outcomes of a study in which a digital mind tool (i-Think) was found to enhance the students' critical thinking [31].

With regards to the lowest means, the data showed that the students barely agreed $(\mathrm{M}=3.69 ; \mathrm{SD}=0.97)$ that the digital mind mapping has wholly developed their critical thinking in writing. They were also slightly agreed $(\mathrm{M}=$ $3.72 ; \mathrm{SD}=0.92)$ that their ability to improve ideas were attributed to digital mind mapping. The third lowest mean depicting the respondents hardly believed $(\mathrm{M}=3.72 ; \mathrm{SD}$ $=0.99$ ) regarding their ability to draw conclusion in their writing was due on the digital mind mapping. 
Table 4. The Use of Digital Mind Map to Stimulate Critical Thinking in Writing

\begin{tabular}{|c|c|c|c|c|}
\hline Item & Construct & M & SD & Interpretation \\
\hline & Recognise assumptions & & & \\
\hline 43 & I recognise my ideas in writing when I use the digital mind map & 3.91 & 0.93 & Agree \\
\hline 44 & I believe recognising ideas in writing is important to stimulate critical thinking & 4.06 & 0.84 & Agree \\
\hline 45 & I develop my critical thinking in writing through digital mind mapping & 3.69 & 0.97 & Agree \\
\hline 46 & $\begin{array}{l}\text { I enhance my critical thinking by recognising main ideas and sub ideas in writing through } \\
\text { the digital mind map }\end{array}$ & 3.75 & 0.95 & Agree \\
\hline 47 & $\begin{array}{l}\text { I improve my confident level in my writing through recognising ideas when I use digital } \\
\text { mind map }\end{array}$ & 3.75 & 0.92 & Agree \\
\hline \multirow[t]{2}{*}{48} & I recognise ideas in writing easily when I used the digital mind mapping & 3.97 & 0.90 & Agree \\
\hline & Evaluate arguments & & & \\
\hline 49 & $\begin{array}{l}\text { I have developed a more focused and systematic way of thinking in my writing when I } \\
\text { used the digital mind map }\end{array}$ & 3.84 & 0.92 & Agree \\
\hline 50 & $\begin{array}{l}\text { I have learnt more about how to evaluate arguments in my writing when I used the digital } \\
\text { mind map }\end{array}$ & 3.81 & 0.93 & Agree \\
\hline 51 & I have learnt more about how to evaluate the main ideas and the sub ideas of writing topic & 3.97 & 0.74 & Agree \\
\hline 52 & I have learnt how to solve problems when I was thinking for more ideas in writing & 4.09 & 0.73 & Agree \\
\hline 53 & $\begin{array}{l}\text { I have learnt how to analyse relevant and irrelevant writing information when I used the } \\
\text { digital mind map }\end{array}$ & 3.94 & 0.76 & Agree \\
\hline \multirow[t]{2}{*}{54} & I have improved my ability in evaluating ideas of writing when I use the digital mind map & 3.72 & 0.92 & Agree \\
\hline & Draw conclusions & & & \\
\hline 55 & I make decision in choosing relevant and irrelevant writing information & 4.03 & 0.70 & Agree \\
\hline 56 & I identify the main ideas and the sub ideas which are related to writing topic & 4.03 & 0.78 & Agree \\
\hline 57 & $\begin{array}{l}\text { I learnt how to decide after I brainstormed my ideas in writing through the digital mind } \\
\text { map }\end{array}$ & 3.94 & 0.80 & Agree \\
\hline 58 & I have developed my skills in drawing conclusion in writing through the digital mind map & 3.87 & 0.97 & Agree \\
\hline 59 & $\begin{array}{l}\text { I have improved my ability in drawing conclusions in writing when I used the digital mind } \\
\text { map }\end{array}$ & 3.75 & 0.92 & Agree \\
\hline \multirow[t]{2}{*}{60} & I found that I can draw conclusion in writing easily when I used the digital mind map & 3.72 & 0.99 & Agree \\
\hline & Total average & 3.88 & 0.74 & Agree \\
\hline
\end{tabular}

Table 5 depicted the overall mean and standard deviation for the three constructs: (i) digital mind map, (ii) creativity, and (iii) critical thinking.

Table 5. Overall Mean and Standard Deviation for Constructs

\begin{tabular}{ccc}
\hline Construct & Mean & Standard Deviation \\
\hline Digital Mind Map & 3.92 & 0.76 \\
\hline Creativity & 3.89 & 0.69 \\
\hline Critical Thinking & 3.88 & 0.74 \\
\hline
\end{tabular}

As shown in Table 5, the results of the three main constructs showed that, in general, the students perceived positively regarding the usage of digital mind map $(\mathrm{M}=$ 3.92; $\mathrm{SD}=0.76)$, their creativity in writing $(\mathrm{M}=3.89$; $\mathrm{SD}$ $=0.69)$ and the critical thinking in writing $(\mathrm{M}=3.88$; $\mathrm{SD}$ $=0.74)$. With regard to Research Question 4, Table 6 showed there was a significant high positive correlation ( $\mathrm{r}$ $=0.94 ; \mathrm{p}<0.05$ ) between the use of digital mind map and students' creativity.
Table 6. Relationship between the Use of Digital Mind Map and Students' Creativity

\begin{tabular}{ccc}
\hline Variable & Creativity & \\
\hline & $\mathrm{r}$ & $\mathrm{p}$-value \\
\hline Use of digital mind map & 0.94 & 0.00 \\
\hline
\end{tabular}

In the same token as posited in Research Question 5, Table 7 also showed that there was a high positive correlation $(r=0.95 ; p<0.05)$ between the use of digital mind map and students' critical thinking.

Table 7. Relationship between the Use of Digital Mind Map and Students' Critical Thinking

\begin{tabular}{ccc}
\hline Variable & \multicolumn{2}{c}{ Critical Thinking } \\
\hline & $\mathrm{r}$ & $\mathrm{p}$-value \\
\hline Use of digital mind map & 0.95 & 0.00 \\
\hline
\end{tabular}

\subsection{Section E: Open-ended Items}

The respondents were also asked to answer six open-ended items in the last part of the questionnaire (Part 
E). This part was designed to identify the reasons and factors that enhance the quality of students' writing using the digital mind map tool. The qualitative data gathered in this section were analysed using thematic analysis. The most frequently emerged theme was ranked as number one. Table 8 illustrated the six open-ended items: A, B, C, $\mathrm{D}, \mathrm{E}$ and $\mathrm{F}$.

Table 8. Results from the Open-ended Items

\begin{tabular}{|c|c|c|c|}
\hline Open-ended Items & Rank & Main Themes & $\begin{array}{c}\text { Frequency } \\
(f)\end{array}$ \\
\hline \multirow{3}{*}{$\begin{array}{l}\text { A. List } 3 \text { main reasons } \\
\text { to use digital mind } \\
\text { maps }\end{array}$} & 1 & Easy to use & 22 \\
\hline & 2 & Save time & 16 \\
\hline & 3 & Add creativity & 13 \\
\hline \multirow{3}{*}{$\begin{array}{l}\text { B. List } 3 \text { factors that } \\
\text { enhance the } \\
\text { respondents' creativity }\end{array}$} & 1 & Easy to colour & 11 \\
\hline & 2 & $\begin{array}{l}\text { Easy to design } \\
\text { shapes }\end{array}$ & 6 \\
\hline & 3 & Wider space & 5 \\
\hline \multirow{3}{*}{$\begin{array}{l}\text { C. List } 3 \text { factors that } \\
\text { enhance my critical } \\
\text { thinking in writing } \\
\text { when using digital } \\
\text { mind mapping. }\end{array}$} & 1 & Elaborate points & 19 \\
\hline & 2 & Solve problems & 9 \\
\hline & 3 & Draw conclusion & 5 \\
\hline \multirow{3}{*}{$\begin{array}{l}\text { D. List } 3 \text { factors that } \\
\text { impede my writing } \\
\text { even if I used digital } \\
\text { mind mapping. }\end{array}$} & 1 & $\begin{array}{l}\text { Lack of } \\
\text { knowledge }\end{array}$ & 10 \\
\hline & 2 & $\begin{array}{l}\text { Slow internet } \\
\text { connection }\end{array}$ & 3 \\
\hline & 3 & $\begin{array}{l}\text { Lack of } \\
\text { confidence }\end{array}$ & 4 \\
\hline \multirow{3}{*}{$\begin{array}{l}\text { E. What other factors } \\
\text { besides creativity and } \\
\text { critical thinking that } \\
\text { will enhance my } \\
\text { writing capabilities. }\end{array}$} & 1 & Knowledge & 14 \\
\hline & 2 & Confidence level & 4 \\
\hline & 3 & Experience & 3 \\
\hline \multirow{2}{*}{$\begin{array}{l}\text { F. Please provide } \\
\text { recommendations to } \\
\text { enhance the quality of } \\
\text { the writing course. }\end{array}$} & 1 & $\begin{array}{l}\text { Provide more } \\
\text { guidance }\end{array}$ & 7 \\
\hline & 2 & $\begin{array}{l}\text { Enhance other } \\
\text { English skills }\end{array}$ & 3 \\
\hline
\end{tabular}

The first open-ended item (section A) asked the students to list three main reasons for using the tool. As shown in Table 8, the students rated easy to use as the highest rank for this item, followed by the other reasons including time saving and creativity. Evidently, it showed that the tool was easy to be used for essays writing. Section B asked the students to list three factors that enhanced their creativity when using the tool. The most important factor that the students answered was easy to colour. Next, the students mentioned that easy to design as the second highest factor that enhanced their creativity. Another factor that the students answered was wider space for them when they were creating the mind maps. These three main factors were pertinent for students in enhancing their creativity for their writing.

In Section $\mathrm{C}$, the students were asked to list three factors that enhanced their critical thinking in writing when using the tool. The highest rank was their ability to elaborate points. They also answered the ability to solve problems and to draw conclusion as the other factors that helped them to improve their critical thinking in writing. Hence, the finding showed that the digital mind tool helped the students to stimulate their critical thinking in writing.

Section D demonstrated the key factors that impeded the students' writing even though they used the tool. As illustrated in Table 8, the highest frequency for barriers was

lack of knowledge. The students explained that they need more knowledge on how the tool could enhance their writing competency. The students also stated that technical problem as the second suppressive factor which is related to a slow internet connection. They also mentioned that, at times, they experienced a lack of confidence when using the tool.

Section E asked the students to list other factors besides creativity and critical thinking that will enhance their writing capabilities. Interestingly, the most rated was knowledge as a major factor that will be able to help the students to improve their writing competency. Next, they answered confidence level as the second highest rank, followed by the experience in using the digital mind map. These factors are highly connected because without experience, the students would not feel very confident in their writing. Nevertheless, if used properly, the mind mapping device has a potential in enhancing the students' confidence level in writing [32]. The final section $(\mathrm{F})$ required the students to provide recommendations to enhance the quality of writing course. In general, the students recommend that they should be given more guidance to improve the quality of their writing. Besides that, the students also highlighted that they need to enhance other English skills such as grammar, reading and vocabulary.

\section{Conclusion}

The purpose of this study was to identify students' perception on the use of digital mind map to stimulate creativity and critical thinking in ESL writing course. Based on the empirical data, the students perceived that the digital mind map tool has helped them to brainstorm ideas and enhanced their writing skills. In terms of creativity, students believed that the tool could stimulate their creativity in ESL writing course. Furthermore, the students also expressed that the digital mind map helped them to think critically in ESL writing course. Specifically, the students perceived the digital mind map was practical for writing. The students agreed that the tool helped them to write faster and efficiently, the appearance and mechanics of the tool have assisted them to organise their ideas easily. In terms of creativity, the students claimed that the tool helped them to be fluent, flexible, original, and able to elaborate in creating and producing ideas creatively for writing. Also, the students found that the tool also facilitated them to stimulate their critical thinking. The tool helped them to recognise their 
assumptions, evaluate arguments and draw conclusions in writing. The finding also confirmed strong positive and significant relationships between the use of digital mind map and the students' creativity and critical thinking in their writing.

\section{REFERENCES}

[1] Mustapha, R., Abdul Rahim, Z.L., and Azman, M.N.A., "Exploring the problems faced by technical school students in learning engineering courses", Journal of Engineering Science and Technology, vol. 9 (6), 2014, pp. 690-701.

[2] Gezmiș, N., "Difficulties faced by the undergraduate students in the process writing approach", Journal of Language and Linguistic Studies, vol. 16 (2), 2020, pp. 565-579. doi: 10.17263/jlls.759249

[3] Mousavi, H.S., and Kashefian-Naeeni, S., "An investigation into the role of EFL learners' attitude, motivation, and proficiency in learning among Iranian students of National University in Malaysia”. European Journal of Social Sciences, vol. 23 (4), 2011, pp. 593-603.

[4] R.A. Karim, A. H. M. Adnan, M. H. M. Tahir, Adam, M.H.M, Idris, N, and Ismail, I, "The Application of Mobile Learning Technologies at Malaysian Universities Through Mind Mapping Apps for Augmenting Writing Performance". Advances in Science Technology and Engineering Systems Journal. vol. 5 (3), 2020, pp. 510-512.

[5] Jensen D, Bauer A, Doria M, Perez KB, Anderson D, and Wood KL., "A bio-inspired mind map to assist in concept generation for wall climbing systems: development, assessment and resulting prototypes". In: ASEE annual conference and exposition, 2018.

[6] Ting-Ju Chen, Ronak R Mohanty, Miguel A Hoffmann Rodriguez, and Vinayak R Krishnamurthy, "Collaborative Mind-Mapping: A Study of Patterns, Strategies, and Evolution of Maps Created by Peer-Pairs". 32nd International Conference on Design Theory and Methodology in International Design Engineering Technical Conferences \& Computers and Information in Engineering Conference, ASME, 2019.

[7] M. Zahedi and L. Heaton, "Mind mapping as a tool, as a process, as a problem/solution space. Proceedings of the $18^{\text {th }}$ International Conference on Engineering and Product Design Education, Aalborg University, Denmark, September 2016, pp.166-171.

[8] Orlova, N.V., "Efficiency of Mind Mapping for The Development of Speaking Skills in Students of Non-Linguistic Study Fields", Science and education, 2017, vol. 6 , pp. 151-161.

[9] R.A. Karim., "Technology-Assisted Mind Mapping Technique in Writing Classrooms: An Innovative Approach", International Journal of Academic Research in Business and Social Sciences, 2018, vol. 8 (4), pp.1092-1103.

[10] Sabbah, S. S., "The Effect of College Students' Self-Generated Computerized Mind Mapping on Their Reading Achievement, International Journal of Education and Development using Information and Communication Technology, 2015, vol. 11 (3), pp. 4-36.

[11] Heethal Jaiprakash, Sanil S Hishan and Suresh Ramakrishnan., "Effectiveness of Mind Mapping as Digital Brainstorming Technique in Enhancing the Writing Skills of Indian Students". International Journal of Psychosocial Rehabilitation, 2020, vol. 28(8) pp. 120-129.

[12] Exswap., Products. Expert Software Application srl: http://www.exswap.com/products.html, 2016.

[13] Keengwe, J., "Handbook of Research on Mobile Technology, Constructivism, and Meaningful learning". University of North Dakota, 2017, USA.

[14] Kalyanasundaram, M. Abraham, S.B, Ramachandran, D, Jayaseelan, V, Bazroy, J, Singh, Z, and Purty, A.J., "Effectiveness of Mind Mapping Technique in Information Retrieval Among Medical College Students in Puducherry-A Pilot Study", Indian Journal Community Medicine, 2017, vol. 42 (1) pp.19- 23

[15] Sehic, S., "The effect of English language learning on creative thinking skills: A mixed methods case study, English Language Teaching, 2017, vol. 10 (3), pp.82-94.

[16] Nino, F., and Paez, M., "Building writing skills in English in fifth graders: Analysis of trategies based on literature and creativity", English Language Teaching, 2018, vol. 11(9), pp. 102-117.

[17] Al-Jarf, R., "Exploring Discourse and Creativity in Facebook Creative Writing by Non-Native Speakers" In M. Danesi (Ed.), Empirical Research on Semiotics and Visual Rhetoric, (pp.1-31), Hershey, PA: IGI Global, 2018.

[18] Sahin, N., \& Polatcan, F., "The Effect of Creative Writing Exercises in Turkish Classes on Students' Academic Achievement: A Meta-Analysis", International Online Journal of Educational Sciences, 2019, vol. 11 (2), 254-268.

[19] Tao-Hua Wang, Hao-Chiang Koong Lin, Ting-Ting Wu, and Yueh-Min Huang., "A Multimethod Approach for Supporting Reflection and Creativity in Online Collaborative Courses", Journal of Internet Technology, 2020, vol. 21 (4), pp.1097-1106.

[20] Alena D. Matraeva, Marina V. Rybakova, Mikhail V. Vinichenko, Aleksander A. Oseev, and Natalia V. Ljapunova., "Development of Creativity of Students in Higher Educational Institutions: Assessment of Students and Experts". Universal Journal of Educational Research, 2020, vol. 8(1), 8 - 16. DOI: 10.13189/ujer.2020.080102.

[21] Hall, S.K., "Practise makes perfect: developing critical thinking and effective writing skills in undergraduate science students", 3rd International Conference on Higher Education Advances, Universitat Politecnica de Valencia, Val'encia, HEAd'17, 1044-1051.

[22] Balta, E.E., “Teachers' Perceptions for Implementation of Integrated Critical Thinking and Writing Skills", GEFAD /GUJGEF, 2017, Vol. 37(2), pp. 737-758

[23] Nawas, A., "Contextual Teaching and Learning (CTL) Approach through REACT strategies on improving the students' critical thinking in writing", International Journal of Management and Applied Science, 2018, vol. 4 (7), pp. 46-49 
[24] Oz, M. and Memis, E.K., "Effect of Multi Modal Representations on the Critical Thinking Skills of the Fifth Grade Students", International Journal of Progressive Education, 2018, 14 (2), pp. 209-227.

[25] Javid, C., and Umer, M., "Saudi EFL learners' writing problems: a move towards solution", Proceeding of the Global Summit on Education GSE, 2014, pp. 4-5

[26] Lin, H., and Faste, H., "The Untapped Promise of Digital Mind Maps", Proceedings of the SIGCHI Conference on Human Factors in Computing Systems, CHI 2012, Austin Texas, USA.

[27] Williams, F. E., "Classroom ideas for encouraging thinking and feeling”, Buffalo, NY: D.O.K Publishers, Inc, 1970.

[28] Watson, Goodwin, and E. M. Glaser, Watson-Glaser., "Critical Thinking Appraisal", Harcourt, Brace \& amp;
World, Inc., 1952.

[29] Ibrahim M.A Jbeili., "The Impact of Digital Mind Maps on Science Achievement among Sixth Grade Students in Saudi Arabia", Procedia - Social and Behavioral Sciences, 2013, vol. 103, pp. 1078-1087

[30] Abdulbaset, H. M., "Digital Mind Maps: Their activities in education and learning". E-Learning Journal, 2016, vol. 12.

[31] Yaakob, N, Abd Rashid A.R and, M.N.A., "Developing Critical Thinking Skills Through i-Think Maps: An Action Research", International Journal of English Linguistics, 2018 , vol. 8 (7).

[32] R.A Karim and Abu, A.G., "Using Mobile-Assisted Mind Mapping Technique (MAMMAT) to Improve Writing Skills of ESL Students", Journal of Social Science and Humanities, 2018, vol. 1(1), 33-38. 